\title{
Haiku Kettengedicht
}

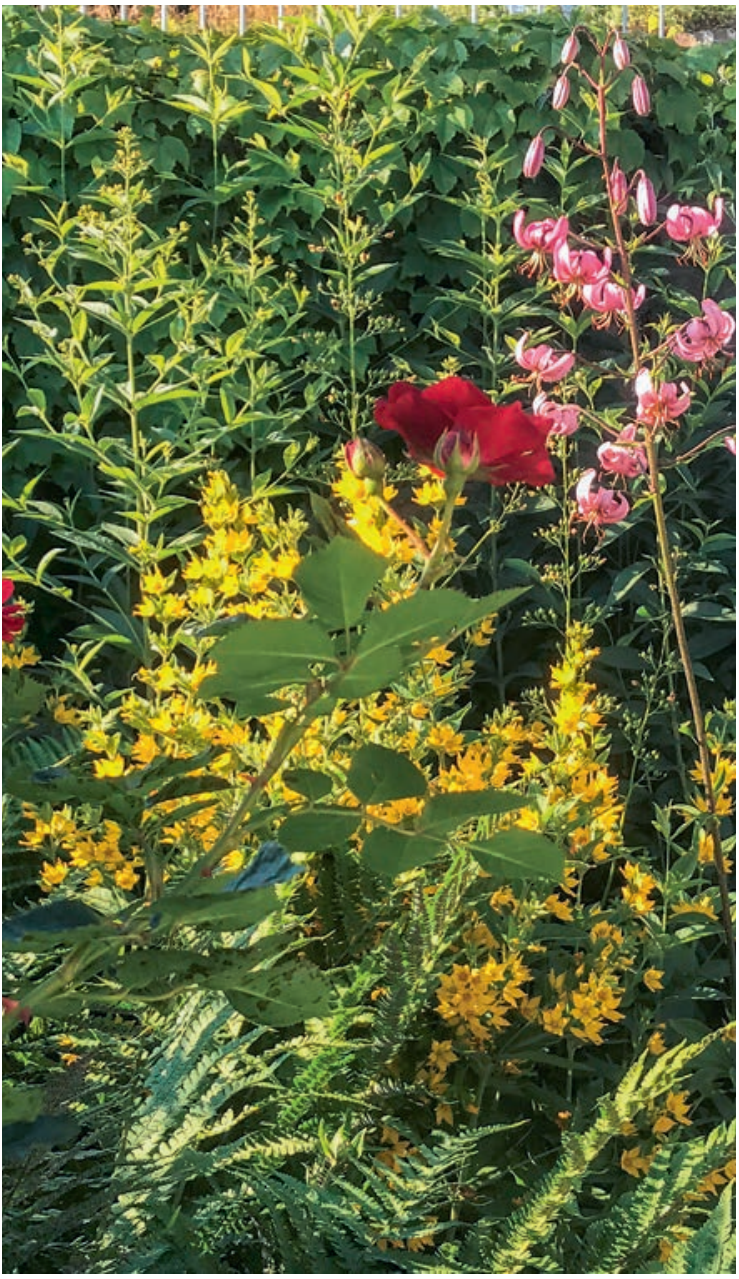

Der Regen spielt ein

Klavierkonzert auf dem Dach-

Fenster in e-Moll

Deine Augen sind

Das Fenster zu Deinem Herz

Licht und Liebe strahlt

Warum verzaubert

Das Licht die Welt? Weil es

Vom Schöpfer erzählt

Du bist der Schöpfer

Deiner Realität, mach

Das Schönste daraus

\section{Realität und}

Traum sind manchmal untrennbar

Zu unserem Glück

Ist nicht das Leben

Der Traum und das Jenseits die

Wahre Wirklichkeit?

Leben ist immer

Kommunikation, Tod

Nur ein Übergang

Dr. med. Hedi Meierhans, Maseltrangen 